\title{
Budowa i funkcja ludzkich antygenów zgodności tkankowej. Czę̧́́ 3. Rola antygenów MHC w chorobach reumatycznych
}

\section{Structure and function of human major histocompatibility antigens. Part 3. The role of MHC antigens in theumatic diseases}

\section{STRESZCZENIE}

Ekspresja określonych alleli zgodności tkankowej stanowi czynnik ryzyka chorób reumatycznych. W reumatoidalnym zapaleniu stawów jest to obecność antygenów HLA-DRB1, z charakterystyczną sekwencją pięciu aminokwasów (glutamina, lizyna, arginina, alanina) w pozycjach od 70 do 74 łańcucha, nazywanych najczęściej wspólnym epitopem. Charakterystyczna dla zesztywniającego zapalenie stawów kręgosłupa jest ekspresja antygenu zgodności tkankowej HLA-B27, który może prezentować nieprawidłowo przetworzone peptydy antygenowe. Wydaje się, że cząsteczki HLA-B27 mogą z większą wydajnością prezentować autoreaktywnym limfocytom T patogenne peptydy bakteryjne albo endogenne peptydy artrytogenne. W biologii chorób reumatycznych ważną rolę mogą odgrywać także polimorfizmy pojedynczego nukleotydu (SNP, single nucleotide polymorphism) czy mechanizmy epigenetyczne, wpływające na ekspresję genów.

Forum Reumatol. 2019, tom 5, nr 1: 33-42

Słowa kluczowe: HLA-DRB1; wspólny epitop; HLA-B27; prezentacja antygenu

\section{WSTEP}

Powiązania pomiędzy ekspresją określonych antygenów zgodności tkankowej a chorobami autoimmunologicznymi budziły zainteresowanie od dawna. Jest to w dużej mierze zrozumiałe, gdyż cząsteczki kompleksu zgodności tkankowej (MHC, major histocompatibility complex) uczestniczą zarówno w fazie indukcji, jak i w fazie efektorowej odpowiedzi immunologicznej, także tej skierowanej przeciwko własnym antygenom. Przykładem chorób autoimmunologicznych, w etiopatogenezie których rolę antygenów MHC dokładniej określono, są reumatoidalne zapalenie stawów i zesztywniające zapalenie stawów kręgosłupa.

\section{REUMATOIDALNE ZAPALENIE STAWÓW}

Reumatoidalne zapalenie stawów (RZS [RA, rheumatoid arthritis]) jest chorobą zapalną, w rozwoju której odgrywają rolę zarówno czynniki środowiskowe, jak i genetyczne. Odziedziczalność RZS jest szacowana na około 40-65\%, przy czym w przypadkach postaci seropozytywnej może sięgać powyżej $60 \%$, a w przypadkach seronegatywnych do $20 \%$ [1-3]. Oszacowano, że w $12 \%$ wiąże się ona $\mathrm{z}$ genami $M H C$, a w około 5,5\% z genami wrażliwości leżącymi poza tym obszarem DNA [4]. W badaniach asocjacyjnych całego genomu (GWAS, genome-wide association study) zidentyfikowano ponad 100 takich genów (a w zasa-
Adres do korespondencji: prof. dr hab. n. med. Krzysztof Wiktorowicz Katedra Biologii i Ochrony Środowiska, Uniwersytet Medyczny im. Karola Marcinkowskiego w Poznaniu

e-mail: wnozbiol@ump.edu.pl 
dzie polimorfizmów pojedynczego nukleotydu [SNPs, single-nucleotide polymorphisms]) na wszystkich chromosomach $\mathrm{z}$ wyjątkiem chromosomu Y $[4,5]$.

Reumatoidalne zapalenie stawów jest chorobą autoimmunologiczną, której etiologii w pełni nie poznano. Objawem zaburzeń w mechanizmach regulacyjnych układu immunologicznego jest między innymi występowanie u znacznego odsetka chorych przeciwciał przeciw immunoglobulinie G (czynnik reumatoidalny, RF, opisany po raz pierwszy siedemdziesiąt lat temu) $[4,6]$, czy przeciwko cytrulinowanym białkom (ACPA anti-citrullinated protein antibody) [4].

\section{ROLA ANTYGENÓW MHC KLASY II W PATOGENEZIE RZS — WSPÓLNY EPITOP}

$\mathrm{Na}$ rolę antygenów zgodności tkankowej w etiopatogenezie choroby wskazują asocjacje pomiędzy allelami HLA (zwłaszcza HLA-DRB) a zachorowaniem na RZS [2, 7]. Bardzo wyraźnie powiązane z RZS są allele DRB1, kodujące łańcuch $\beta$ antygenu HLA-DR. Łańcuch ten u większości pacjentów z RZS ma charakterystyczną sekwencję pięciu aminokwasów (tj. QKRAA, QRRAA lub RRRAA; Q to glutamina, K - lizyna, R - arginina, A - alanina) w pozycjach od 70 do 74 , nazywanych najczęściej wspólnym epitopem (SE, shared epitope syn. rheumatoid pocket, susceptibility cassette) [8]. Trzy z nich (reszta 70, 71 i 74) biorą udział w uformowaniu kieszeni 4 wiążącej peptyd antygenowy, natomiast dodatnio naładowane lizyna czy arginina ułatwiają wiązanie peptydów o dodatnim ładunku znajdujących się w odpowiadającej pozycji [9] (ryc. 1). W badaniach osób chorych na RZS we Francji stwierdzono, że ryzyko zachorowania było powiązane $\mathrm{z}$ aminokwasem $\mathrm{w}$ pozycji 71 (większe ryzyko w przypadku K > T > A lub E) i w pozycji 72 (Q lub R > D) [10]. Chociaż obserwacje te sugerują wpływ wspólnego epitopu na zdolność wiązania przez cząsteczkę HLA-DR określonych peptydów, to istnieje możliwość, że samo ukształtowanie łańcucha spowodowane taką sekwencją aminokwasów może ułatwiać wiązanie receptorów wrodzonej odpowiedzi immunologicznej, co indukuje produkcję wolnych rodników i w ten sposób sprzyja powstawaniu choroby [11].

Ekspresja alleli HLA mających wspólny epitop jest związana $\mathrm{z}$ występowaniem przeciwciał przeciwko cytrulinowanym (ACPA), karbamylowanym (anty-CarP) i acetylowanym białkom. Takie potranslacyjne modyfikacje białek, polegające na zamianie lizyny w cytrulinę lub, odpowiednio, w homocytrulinę czy dołączeniu do lizyny grupy metylowej $[12,13]$, mogą zmniejszać ich wrażliwość na działanie proteaz, w wyniku czego powstające peptydy różnią się od peptydów uwalnianych w wyni$\mathrm{ku}$ trawienia białek natywnych. Zmodyfikowane aminokwasy mają podobną strukturę przestrzenną, która, wraz z utratą dodatniego ładunku, może ułatwiać ich wiązanie nie tylko z cząsteczkami HLA-DR [14, 15] (np. kieszeń 4.HLA-DRB1*04: 01/04, wykazującym powiązanie $\mathrm{z}$ podatnością na RZS wiąże silnie cytrulinę [14]), ale także z HLA-DQ [16], przy czym na siłę wiązania może wpływać także struktura całego peptydu [15]. Prawdopodobnie przyczyną indukcji wytwarzania przeciwciał jest więc rozpoznawanie zmodyfikowanych peptydów przez limfocyty $\mathrm{T}$ jako neoantygenu [15]. Przemawia za tym fakt, że przeciwciała ACPA i anty-CarP mogą reagować krzyżowo [17]. Podatność na RZS może być związana z resztami aminokwasowymi w pozycji 11 i/lub 13 na dnie rowka HLA-DR, co także wskazuje na rolę prezentacji antygenów w etiopatogenezie choroby $[8,18]$, gdyż w badaniu radiologicznym obserwowano większe uszkodzenia kostne w przypadkach, kiedy w pozycji 11 łańcucha HLA-DRB1 znajdowała się walina [19]. U pacjentów z autoprzeciwciałami czynnikami ryzyka są także polimorfizmy pojedynczych aminokwasów w pozycjach 9 łańcucha HLA-B, 9 HLA-DPB i 77 HLA-A [18, 20] a także, zwłaszcza u Japończyków, mutacje w genie $H L A-D O$ [21].

Jedna $\mathrm{z}$ hipotez tłumacząca te różnice przyjmuje, że to nie ekspresja pojedynczych alleli HLA, ale określone haplotypy, zawierające oprócz określonych zestawów antygenów zgodności tkankowej inne geny, wchodzące $\mathrm{z}$ nimi w interakcje, mogą wpływać na działanie regulatorowych limfocytów T, umożliwiając rozwój odpowiedzi autoimmunologicznej [22]. Potwierdzeniem tej teorii mogą być obserwacje o związku pewnych haplotypów MHC klasy III z podatnością na zachorowanie i przebiegiem RZS [23, 24].

Hipoteza ta może tłumaczyć obserwację, że ekspresja alleli (np. HLA-DRB*13), które w pozycjach 70 do 74 mają sekwencję DERAA (D-kwas asparaginowy, E-kwas glutaminowy), wydaje się chronić przed RZS [3, 8]. Działanie ochronne może być uwarunkowane przez silną nierównowagę sprzężeń pomiędzy allelami HLA-SE i HLA-DQ, czyli występowanie pewnych haplotypów, zawierających określone allele HLA-DR i HLA-DQ. Cząsteczki HLA-DQ, występujące w haplotypach chroniących 


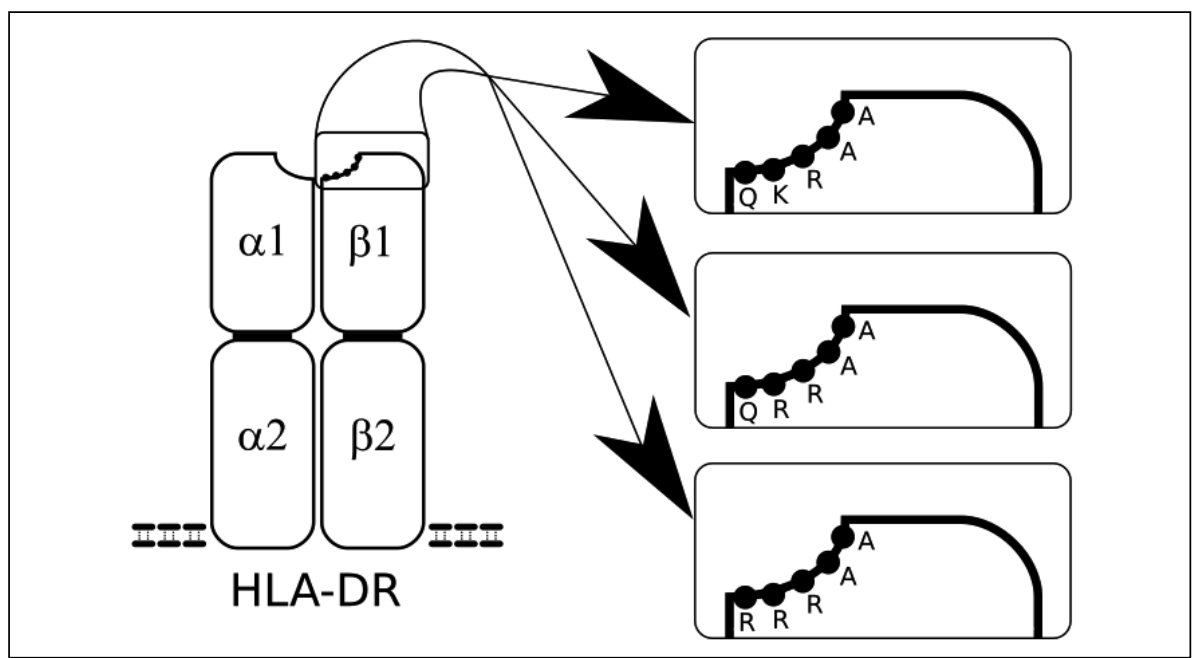

Rycina 1. Schemat ułożenia pięciu aminokwasów w łańcuchu HLA-DRB1, tworzących „wspólny epitop”. (Q — glutamina, K — lizyna, R — arginina, A — alanina)

przed RZS są bowiem zdolne do wydajnego prezentowania epitopów DERAA pochodzących z mikroorganizmów bądź autoantygenów, także ze zdegradowanych łańcuchów HLA-DRB. Jeśli do takiej prezentacji dochodzi w grasicy, to w trakcie dojrzewania limfocytów $\mathrm{T}$ delecji ulegają klony z receptorami rozpoznające taką sekwencję. W konsekwencji, jeśli nawet $w$ organizmie pojawi się autoantygen zawierający peptyd DERAA, rozpoznawany przez limfocyty B, to brak wspomagania ze strony pomocniczych limfocytów T uniemożliwia produkcję przeciwciał przeciwko tym antygenom, blokując reakcje autoimmunologiczne [25].

\section{NIEKLASYCZNE ANTYGENY ZGODNOŚCI TKANKOWEJ}

Na udział cząsteczek MHC w aktywnej regulacji odpowiedzi immunologicznej wskazują także powiązania RZS z niektórymi nieklasycznymi antygenami zgodności tkankowej klasy I, jak MICA [26, 27, 28] i MICB [29] czy HLA-E [30] lub HLA-G [31]. Wpływ określonych alleli na rozwój i przebieg choroby może być trudny do oceny, nie tylko ze względu na nierównowagę sprzężeń, ale także polimorfizmy pojedynczego nukleotydu (SNP) [28].

\section{RÓŻNICE POPULACYJNE ASOCJACJI POMIĘDZY ANTYGENAMI ZGODNOŚCI TKANKOWEJ A RZS}

Niektóre sprzeczności dotyczące asocjacji pomiędzy antygenami zgodności tkankowej a RZS może tłumaczyć zróżnicowanie populacyjne. Przykładem mogą być antygeny HLA-
-DQ, które w analizie północnoamerykańskich baz danych wykazywały istotne powiązania z RZS [32], natomiast w materiale pochodzącym z Wielkiej Brytanii - nie [33]. Podobne rozbieżności dotyczą ekspresji wewnątrzkomórkowej cząsteczki HLA-DM, w przypadku której wykazano asocjację z RZS w populacji francuskiej [34], a czego nie zaobserwowano w badaniach przeprowadzonych w Stanach Zjednoczonych [35]. W przypadku transaktywatora CIITA różnice w budowie cząsteczki wykazują związek z RZS przede wszystkim w populacji skandynawskiej [36].

\section{ZESZTYWNIAJACE ZAPALENIE STAWÓW KREGGOSŁUPA (ZZSK)}

Czynnikiem genetycznym, charakterystycznym dla spondyloartropatii, jest ekspresja antygenu zgodności tkankowej HLA-B27. Jego obecność wykazano u ponad $90 \%$ chorych na zesztywniające zapalenie stawów kręgosłupa (ZZSK), u $76 \%$ na młodzieńcze zapalenie stawów towarzyszące zapaleniu przyczepów ścięgnistych, u 30-75\% na reaktywne zapalenie stawów (ReA) i zapalenie stawów towarzyszące enteropatiom oraz u 40-50\% na łuszczycowe zapalenie stawów [37]. Choć pierwsze doniesienia na ten temat pochodzą z lat 70. XX wieku, do dziś brak jednoznacznego wyjaśnienia udziału antygenu HLA-B27 w patogenezie tych chorób. W bazie IPD-IMGT/HLA zamieszczono ponad 160 alleli HLA-B27 (od B*27:01 do B*27:164). Ekspresja najpowszechniej występującego w populacji kaukaskiej, prawdopodobnie pierwotnego (ancestral) allelu HLA-B*27:05 jest silnie po- 


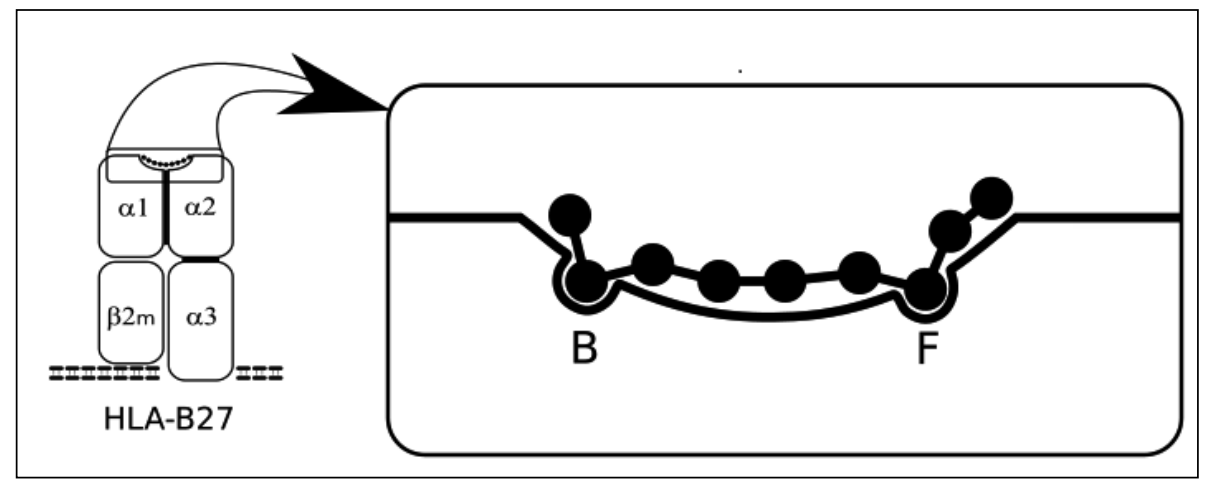

Rycina 2. Schemat oddziaływania peptydu antygenowego z HLA-27. B, F — kieszenie w rowku wiążącym cząsteczki MHC klasy I

wiązana z ZZSK. Większość alleli B27 występuje rzadko, więc ich związek z ZZSK trudno oszacować. Niemniej jednak, co najmniej dwa allele, HLA-B*27:06 i HLA-B*27:09, nie są czynnikami ryzyka ZZSK [37, 38].

\section{PREZENTACJA ANTYGENU PRZEZ CZASTECZKI HLA-B27}

Peptydy o długości od 8 do 33 aa [37, 39], wiązane przez cząsteczki HLA-B27, muszą mieć odpowiednią konformację. Aminokwas na końcu aminowym (P1) wiążę się w kieszeni A, tworząc sieć wiązań wodorowych przy udziale cząsteczki wody z trzema resztami tyrozyny łańcucha ciężkiego (Tyr7, Tyr59 i Tyr171) [40]. Kieszeń B mająca kwas glutaminowy w pozycji 45 i cysteinę w 67 wiąże praktycznie tylko argininę w pozycji P2 (jedynie ok. 3\% związanych peptydów ma w tej pozycji glutaminę) [37, 40]. Koniec karboksylowy peptydu wiąże się przez kieszeń $\mathrm{F}$, a swoistość tego wiązania może zależeć od aminokwasu, zajmującego pozycję 116 (na dnie rowka wiążącego). W allelach B*27:05, B*27:04 i B*27:02 w miejscu tym znajduje się kwas asparaginowy, zaś w B*27:09 histydyna, a w B*27:06 tyrozyna. Ponadto $\mathrm{B}^{*}$ 27:06 różni się od $\mathrm{B} * 27: 04$ (będącym czynnikiem ryzyka w populacji azjatyckiej) podstawieniem kwasu asparaginowego w miejsce histydyny w pozycji $114[37,38,40]$. Te zamiany aminokwasów w obrębie kieszeni F mogą wpływać na repertuar wiązanych peptydów, przy czym stabilność konformacji tej kieszeni w allelu HLA-B*27:05 jest niższa niż w HLA-B*27:09 [41] (ryc. 2). Oprócz znanych od wielu lat związków choroby z allelami HLA-B27 [37], w badaniach asocjacyjnych całego genomu znaleziono korelacje także pomiędzy ZZSK a polimorfizmami pojedynczego nukleotydu w allelach retikularnych aminopeptydaz ERAP1, ERAP2, LNPEP (aminopeptydaza leucylo-cystynylowa) oraz cytoplazmatycznej aminopeptydazy alaninowej NPEPPS (uczestniczącej w obróbce peptydów opuszczających proteasomy) [37, 42]. Zaobserwowano też, że wyższa aktywność ERAP1 wiązała się ze zwiększonym ryzykiem ZZSK [38]. Enzym ten jest kodowany przez gen, leżący na 15 chromosomie, wykazujący kodominację, wobec czego u każdej osoby występują jego dwa allotypy. Badania funkcjonalne wykazały, że pary allotypów ERAP1 występujące u chorych na ZZSK mało wydajnie generowały ligandy peptydowe zdolne do wiązania się z HLA-B*2705 [43]. W genach kodujących ten enzym występują liczne polimorfizmy pojedynczych nukleotydów (SNP), a więc u pacjentów z ZZSK mogą występować odmiany enzymów (allotypy) różniące się aktywnością i udziałem w patogenezie choroby [44]. Występowanie wariantu ERAP1 z polimorfizmami rs30187, K528R jest ograniczone do osób z HLA-B27 [45, 46].

$\mathrm{W}$ procesie prezentacji ważną rolę odgrywają także, poza aminopeptydazami, inne białka. U pacjentów z ZZSK występuje jeden z alleli endopeptydazy PSMB9 (LMP2), składnika proteasomów [47], którego obecność koreluje z progresją choroby [48]. Opisano także powiązania ZZSK z niektórymi wariantami transporterów TAP [49], przenoszącymi peptydy powstające $\mathrm{w}$ wyniku działania proteasomów do retikulum, gdzie mogą się wiązać z cząsteczkami MHC klasy I. Wszystkie te obserwacje wskazują, że rola HLA-B27 w zesztywniającym zapaleniu stawów kręgosłupa wiąże się z mechanizmami, powodującymi nieprawidłowe przetwarzanie peptydów antygenowych. Wydaje się, że cząsteczki HLA-B27 mogą $\mathrm{z}$ większą wydajnością prezentować autoreaktywnym limfocytom $\mathrm{T}$ patogenne peptydy bakteryjne albo endogenne peptydy artrytogenne. Być może antygeny HLA-B mogą wiązać także znacznie większe, niezdegradowane cząstecz- 
ki, gdyż w przypadku HLA-B*57:01 zaobserwowano niekowalencyjne łączenie abakawiru (analogu guanozyny) z kieszenią F [50].

\section{ZMIANY KONFORMACJI CZASTECZEK HLA-B27}

Zwijanie HLA-B27 w porównaniu z większością cząsteczek MHC klasy I jest bardzo wolne. W siateczce endoplazmatycznej łańcuch ciężki pozostaje długo związany z białkiem opiekuńczym BiP (binding immunoglobulin protein) [51]. To i nietypowe właściwości struktury zarówno kieszeni B [37], jak i F [41] może powodować nieefektywne ładowanie peptydów i hamować transport cząsteczki na powierzchnię komórki. W tych warunkach wzrasta prawdopodobieństwo tworzenia oligomerów (w których tworzeniu uczestniczy niesparowana reszta cysteiny 167 rowka wiążącego) [52], co może indukować stres retikulum endoplazmatycznego, a w następstwie odpowiedź na niepoprawnie zwinięte białka (UPR, unfolded protein response) [37].

Zarówno homodimery łańcuchów ciężkich HLA-B27 (bez $\beta 2$ mikroglobuliny), jak i same łańcuchy ciężkie są wykrywane na powierzchni komórki. Prawdopodobnie powstają one $\mathrm{z}$ prawidłowych cząsteczek, które utraciły związany peptyd. Tworzenie homodimeru może zachodzić w kwaśnym środowisku endosomu (po internalizacji z błony komórkowej) umożliwiającym częściowe rozwijanie cząsteczek, w następstwie czego niesparowane reszty cysteinowe w pozycji 67 rowka wiążącego tworzą wiązanie siarczkowe. Homodimery zachowują przynajmniej częściowo funkcjonalną konformację i tym samym mogą prezentować peptydy limfocytom T. Ponadto reagują z immunoregulacyjnymi receptorami wrodzonej odpowiedzi immunologicznej, co może indukować reakcje zapalne [37, 53]. Opisano, że w odróżnieniu od „prawidłowych” cząsteczek HLA-B27 zarówno homodimery, jak i łańcuchy ciężkie, silniej wiążą tak zwany immunoglobulinopodobny receptor komórek cytotoksycznych KIR3DL2, w porównaniu z innymi cząsteczkami MHC klasy I, co może powodować ekspansję prozapalnych limfocytów T, wykazujących ekspresję tej formy receptora [54].

Dostępne dane nie pozwalają jednak na jednoznaczne określenie, które z właściwości HLA-B27 są najistotniejsze w rozwoju ZZSK: zdolność do prezentacji szerokiego repertuaru peptydów, indukcja odpowiedzi na niepoprawnie zwinięte białka czy nieswoistej odpowiedzi zapalnej.

\section{INNE ANTYGENY ZGODNOŚCI TKANKOWEJ WYKAZUJACE ASOCJACJE Z ZZSK}

Wpływ MHC na odziedziczalność ZZSK szacuje się na 24-33\%, z czego wpływ samego HLA-B27 stanowi około 16-20\% [46, 55]. Innymi allelami HLA-B, których ekspresja może stanowić predyspozycję do rozwoju choroby jest HLA-B*14: 03, co zaobserwowano w populacjach subsaharyjskich [56], HLA-B*60 i HLA-B*39 (w populacjach wschodnio azjatyckich) [57, 58], HLA-B*38, HLA-B*40 i HLA-B*52 [59], a także $B^{*} 13: 02$, B*40:01, B*40:02, B*47:01, B*51:01 [46].

Antygeny zgodności tkankowej klasy II, wykazujące asocjację z ZZSK, to HLA-DR (HLA-DR4) i HLA-DP (DPA1*01: 03, DPA1*02: 01 i DPB1*13: 01) [60].

Opisano także powiązania ZZSK z nieklasycznymi antygenami zgodności tkankowej, choć mogą one być ograniczone do niektórych populacji, na przykład u mieszkańców Sardynii chorych na ZZSK wykazano większą częstość występowania allelu HLA-E*01:01. Oba funkcjonalne allele HLA-E*01:01 i HLA-E*01:03 prezentują w warunkach fizjologicznych peptydy pochodzące z sekwencji sygnałowych klasycznych antygenów transplantacyjnych, lecz wariant częściej występujący na Sardynii reaguje z mniejszym powinowactwem z cząsteczkami sygnałowymi pochodzącymi z HLA-B27, co może upośledzać jego działanie immunoregulacyjne [61]. Podatność zachorowanie może być także związana z obecnością niektórych genotypów alleli HLA-F (F*01:01:01/F*01:03:01) [62].

W badaniach kohortowych zidentyfikowano także allele innych nieklasycznych antygenów zgodności tkankowej MICA jako czynnik ryzyka ZZSK u Amerykanów pochodzenia europejskiego i Chińczyków Han: MICA*007:01 (w białej i żółtej grupie etnicznej) i MICA*019 (u chińskich pacjentów z ZZSK) [63].

\section{MECHANIZMY GENETYCZNE, MOGACE WPLYWAĆ NA OCENE ROLI MHC W CHOROBACH REUMATYCZNYCH}

Badania roli genów w patogenezie chorób autoimmunologicznych (w tym RZS i ZZSK) opierały się głównie na analizie asocjacji pomiędzy obecnością określonych produktów białkowych danego genu (cząsteczek, antygenów) a objawami choroby. Wyniki tych badań przyniosły wiele ważnych ustaleń dotyczących 
możliwego udziału cząsteczek antygenów zgodności tkankowej w patogenezie chorób reumatycznych, choć analiza taka mogła być obciążona pewnymi błędami, związanymi między innymi ze zjawiskami epistazy (kiedy produkty ekspresji jednych genów wpływają na aktywność innych genów niebędących ich allelami) [38, 64-66] czy niezrównoważenia sprzężeń [5, 21, 29, 67]. Rozwój technik biologii molekularnej umożliwił poszukiwanie współzależności pomiędzy określonymi różnicami w zapisie genetycznym (polimorfizmami DNA) a etiopatogenezą szeregu chorób. W przydatku RZS i AS znaleziono szereg powiązań pomiędzy polimorfizmami pojedynczego nukleotydu (SNP) a ryzykiem zachorowania czy przebiegiem choroby [68-71].

\section{POLIMORFIZM POJEDYNCZEGO NUKLEOTYDU}

Polimorfizm pojedynczego nukleotydu to różnica pojedynczego nukleotydu w sekwencji DNA w danym regionie chromosomu w porównaniu $\mathrm{z}$ innymi osobnikami danego gatun$\mathrm{ku}$ lub chromosomem homologicznym tego samego osobnika (oznaczana skrótem rs i numerem). Zamiana w obrębie genu (np. powodująca zmianę kodonu) lub sekwencji regulatorowych może skutkować zmianami w syntezie lub budowie białka, a w konsekwencji różną podatnością na rozwój choroby. Jako przykład może posłużyć antygen HLA-B*27:05, silnie powiązany z ZZSK, który od HLA-B*27:09, nie będącym czynnikiem ryzyka, różni się tylko jednym aminokwasem w pozycji 116 (His/Asp) [72]. Polimorfizmy nukleotydów w obrębie HLA-E mogą wiązać się z podatnością na RZS [30] i ZZSK [62]. Opisano także wpływ niektórych SNP na ekspresję MHC. Zamiana w pozycji 67 asparaginy na kwas asparaginowy powoduje obniżenie ekspresji HLA-B *27:04 na powierzchni komórek i zmniejszenie tworzenia homodimerów [73]. W części przypadków zidentyfikowano powiązania funkcji antygenów zgodności tkankowej z SNP. Polimorfizm pojedynczego nukleotydu rs1051792, co powoduje wymianę waliny na metioninę w pozycji 129 łańcucha MICA zwiększa powinowactwo antygenu do receptora NKG2D komórek NK (natural killer), co skutkuje silniejszą stymulacją tych komórek, większą degranulacją i wytwarzaniem IFN- $\gamma$ [74]. Analogiczny mechanizm może tłumaczyć powiązania pomiędzy występowaniem RZS a ekspresją MICA250 (rs1051794, wymiana lizyny na kwas glutaminowy w pozycji 196) (rzs11). Badania
SNP dostarczają także danych, wskazujących, że podatność na choroby reumatyczne może być związana z interakcjami genów HLA klasy II, na przykład w populacji tunezyjskiej jednoczesne występowanie wariantu rs6457617*TT HLA-DQB1 wraz HLA-DRB1*04 wykazywało powiązanie z podatnością na RZS [75].

\section{EPIGENETYCZNA REGULACJA EKSPRESJI GENÓW MHC}

W patogenezie chorób reumatycznych równie ważną rolę jak czynniki genetyczne odgrywają czynniki środowiskowe. Mechanizmem łączącym te uwarunkowania może być epigenetyczna regulacja ekspresji genów, czyli taka zmiana ekspresji genu, która zachodzi bez zmiany sekwencji DNA. Zmiany te uwarukowane są modyfikacjami DNA i zmianami kondensacji chromatyny, spowodowanymi dołączaniem do ogonów histonowych reszt acetylowych, metylowych, fosforanowych czy ubikwityny. Dołączenie grup metylowych do cytozyny czy zwiększenie stopnia kondensacji chromatyny wycisza (uniemożliwia „odczyt”) gen. Działając na tej drodze, czynniki środowiskowe mogą powodować, że w identycznych genetycznie komórkach lub organizmach dochodzi do różnej ekspresji genów, czego efektem są różnice fenotypowe. Nie tylko brak lub obecność produktu genu, a także jego stężenie może także wpływać na fenotyp, czego przykładem jest obserwacja, że osoby homozygotyczne pod względem HLA-B27 są bardziej narażone na ZZSK [76]. Ekspresja antygenów HLA także podlega regulacji epigenetycznej [77-79]. W chorobach reumatycznych opisano liczne modyfikacje epigenetyczne [80-82], lecz badania dotyczące takiej regulacji ekspresji antygenów HLA są w fazie początkowej [82-85].

\section{MOŻLIWOŚCI TERAPEUTYCZNE}

Można zatem przewidywać, że dalsze badania SNP i mechanizmów epigenetycznych w chorobach reumatycznych, w połączeniu z dotychczasową wiedzą o roli antygenów zgodności tkankowej w tych chorobach, spowodują opracowanie nowych metod terapii. $\mathrm{Z}$ jednej strony podkreśla się ciągle ważną rolę czynnika martwicy nowotworu alfa (TNF-alfa, tumor necrosis factor alpha) w patogenezie chorób reumatycznych o podłożu zapalnym i pomimo pojawiania się leków biologicznych skierowanych przeciwko innym cytokinom 
prozapalnym (IL-6, IL-17, IL-22, IL-23) zachęca się lekarzy praktyków do stosowania w pierwszej linii preparatów anty-TNF-alfa. $\mathrm{Z}$ drugiej strony obserwuje się pojawianie tak zwanych syntetycznych celowanych leków modyfikujących przebieg choroby, czyli tak zwanych inhibitorów kinaz JAK. Leki te, ingerując w mechanizmy wewnątrzkomórkowe komórek syntetyzujących cytokiny prozapalne, blokują ich produkcję. Badania kliniczne oraz kilkuletnie doświadczenia pokazują, że skuteczność inhibitorów kinaz JAK jest zbliżona do obserwowanej po zastosowaniu leków biologicznych, co znalazło już odzwierciedlenie w najnowszych zaleceniach EULAR i stwarza dla reumatologii obiecujące perspektywy.

\section{ABSTRACT}

Expression of particular histocompatibility alleles is a risk factor for rheumatic diseases. In rheumatoid arthritis patients such a marker is the presence of HLA-DRB1 antigens, having a characteristic sequence of five amino acids (glutamine, lysine, arginine, alanine) in positions 70 to 74 of the chain, commonly referred to as a shared epitope (SE). Characteristic for ankylosing spondylitis is the expression of the histocompatibility antigen HLA-B27, which may present incorrectly processed antigenic peptides. It appears that HLA-B27 molecules can show more efficiently bacterial pathogenic peptides or endogenous arthritic peptides to autoreactive T cells Single nucleotide polymorphisms (SNPS) or epigenetic mechanisms regulating the expression of genes also can influence the biology of rheumatic diseases.

Forum Reumatol. 2019, tom 5, nr 1: 33-42

Key words: HLA-DRB1; shared epitope; HLA-B27; antigen presentation
1. MacGregor AJ, Snieder H, Rigby AS, et al. Characterizing the quantitative genetic contribution to rheumatoid arthritis using data from twins. Arthritis Rheum. 2000; 43(1): 30-37, doi: 10.1002/1529-0131(200001)43:1<30::AID-ANR5 > 3.0.C0;2-B, indexed in Pubmed: 10643697.

2. Smolen JS, Aletaha D, Mclnnes IB. Rheumatoid arthritis. Lancet. 2016; 388(10055): 2023-2038, doi: 10.1016/S0140-6736(16)30173-8, indexed in Pubmed: 27156434.

3. Knevel R, Huizinga TWJ, Kurreeman F. Genomic Influences on Susceptibility and Severity of Rheumatoid Arthritis. Rheum Dis Clin North Am. 2017; 43(3): 347-361, doi: 10.1016/..rdc.2017.04.002, indexed in Pubmed: 28711138 .

4. Terao C, Raychaudhuri S, Gregersen PK. Recent Advances in Defining the Genetic Basis of Rheumatoid Arthritis. Annu Rev Genomics Hum Genet. 2016; 17: 273-301, doi: 10.1146/annurev-genom-090314-045919, indexed in Pubmed: 27216775.

5. Yarwood A, Huizinga TWJ, Worthington J. The genetics of rheumatoid arthritis: risk and protection in different stages of the evolution of RA. Rheumatology (Oxford). 2016; 55(2): 199-209, doi: 10.1093/rheumatology/keu323, indexed in Pubmed: 25239882.

6. ROSE HM, RAGAN C. Differential agglutination of normal and sensitized sheep erythrocytes by sera of patients with rheumatoid arthritis. Proc Soc Exp Biol Med. 1948; 68(1): 1-6, indexed in Pubmed: 18863659.

7. Viatte $S, B a r t o n A$. Genetics of rheumatoid arthritis susceptibility, severity, and treatment response. Semin Immunopathol. 2017; 39(4): 395-408, doi: 10.1007/s00281-0170630-4, indexed in Pubmed: 28555384.
8. van Drongelen V, Holoshitz J. Human Leukocyte Antigen-Disease Associations in Rheumatoid Arthritis. Rheum Dis Clin North Am. 2017; 43(3): 363-376, doi: 10.1016/j. rdc.2017.04.003, indexed in Pubmed: 28711139.

9. Kampstra ASB, Toes REM. HLA class II and rheumatoid arthritis: the bumpy road of revelation. Immunogenetics. 2017; 69(8-9): 597-603, doi: 10.1007/s00251-0170987-5, indexed in Pubmed: 28695293.

10. Michou L, Croiseau P, Petit-Teixeira E, et al. European Consortium on Rheumatoid Arthritis Families. Validation of the reshaped shared epitope HLA-DRB1 classification in rheumatoid arthritis. Arthritis Res Ther. 2006; 8(3): R79, doi: 10.1186/ar1949, indexed in Pubmed: 16646982.

11. de Almeida DE, Ling S, Holoshitz J. New insights into the functional role of the rheumatoid arthritis shared epitope. FEBS Lett. 2011; 585(23): 3619-3626, doi: 10.1016/j.febslet.2011.03.035, indexed in Pubmed: 21420962.

12. Derksen VF, Huizinga TWJ, van der Woude D. The role of autoantibodies in the pathophysiology of rheumatoid arthritis. Semin Immunopathol. 2017; 39(4): 437-446, doi: $10.1007 / s 00281-017-0627-z$, indexed in Pubmed: 28451788.

13. van der Woude D, Toes REM. The contribution of autoantibodies to post-translationally modified proteins to inflammatory arthritis. Curr Opin Rheumatol. 2017; 29(2): 195200, doi: 10.1097/BOR.0000000000000371, indexed in Pubmed: 27977623.

14. Scally SW, Petersen J, Law SC, et al. A molecular basis for the association of the HLA-DRB1 locus, citrullination, and rheumatoid arthritis. J Exp Med. 2013; 210(12): 2569-2582, doi: 10.1084/jem.20131241, indexed in Pubmed: 24190431. 
15. Sidney J, Becart S, Zhou M, et al. Citrullination only infrequently impacts peptide binding to HLA class II MHC. PLoS One. 2017; 12(5): e0177140, doi: 10.1371/journal. pone.0177140, indexed in Pubmed: 28481943.

16. Kampstra ASB, van Heemst J, Moustakas AK, et al. The increased ability to present citrullinated peptides is not unique to HLA-SE molecules: arginine-to-citrulline conversion also enhances peptide affinity for HLA-DQ molecules. Arthritis Res Ther. 2016; 18(1): 254, doi: 10.1186/s13075-0161153-4, indexed in Pubmed: 27809896.

17. Reed E, Jiang X, Kharlamova N, et al. Antibodies to carbamylated -enolase epitopes in rheumatoid arthritis also bind citrullinated epitopes and are largely indistinct from anti-citrullinated protein antibodies. Arthritis Res Ther. 2016; 18(1): 96, doi: 10.1186/s13075-016-1001-6, indexed in Pubmed: 27145822.

18. Raychaudhuri S, Sandor $C$, Stahl EA, et al. Five amino acids in three HLA proteins explain most of the association between MHC and seropositive rheumatoid arthritis. Nat Genet. 2012; 44(3): 291-296, doi: 10.1038/ng.1076, indexed in Pubmed: 22286218.

19. Viatte S, Plant D, Han B, et al. Association of HLA-DRB1 haplotypes with rheumatoid arthritis severity, mortality, and treatment response. JAMA. 2015; 313(16): 1645-1656, doi: 10.1001/jama.2015.3435, indexed in Pubmed: 25919528.

20. Han B, Diogo D, Eyre $S$, et al. Fine mapping seronegative and seropositive rheumatoid arthritis to shared and distinct HLA alleles by adjusting for the effects of heterogeneity. Am J Hum Genet. 2014; 94(4): 522-532, doi: 10.1016/j. ajhg.2014.02.013, indexed in Pubmed: 24656864.

21. Okada $Y$, Suzuki A, Ikari $K$, et al. Contribution of a Non-classical HLA Gene, HLA-DOA, to the Risk of Rheumatoid Arthritis. Am J Hum Genet. 2016; 99(2): 366-374, doi: 10.1016/j.ajhg.2016.06.019, indexed in Pubmed: 27486778.

22. Zanelli E, Breedveld FC, de Vries RR. HLA association with autoimmune disease: a failure to protect? Rheumatology (0xford). 2000; 39(10): 1060-1066, indexed in Pubmed: 11035123.

23. Singal DP, Li J, Zhu Y. HLA class III region and susceptibility to rheumatoid arthritis. Clin Exp Rheumatol. 2000; 18(4): 485-491, indexed in Pubmed: 10949724.

24. Yau ACY, Tuncel J, Haag S, et al. Conserved 33-kb haplotype in the MHC class III region regulates chronic arthritis. Proc Natl Acad Sci U S A. 2016; 113(26): E3716-E3724, doi: 10.1073/pnas.1600567113, indexed in Pubmed: 27303036.

25. van Heemst J, Jansen DT, Polydorides S, et al. Crossreactivity to vinculin and microbes provides a molecular basis for HLA-based protection against rheumatoid arthritis. Nat Commun. 2015; 6: 6681, doi: 10.1038/ncomms7681, indexed in Pubmed: 25942574.

26. Lee $\mathrm{YH}$, Bae SC, Kim JH, et al. Meta-analysis of the association between functional MICA-TM polymorphisms and systemic lupus erythematosus, rheumatoid arthritis and ankylosing spondylitis. Z Rheumatol. 2015; 74(2): 146-152, doi: 10.1007/s00393-014-1409-9, indexed in Pubmed: 25060517.

27. Martinez A, Fernandez-Arquero M, Balsa A, et al. Primary association of a MICA allele with protection against rheumatoid arthritis. Arthritis Rheum. 2001; 44(6): 1261-1265, doi: $\quad 10.1002 / 1529-0131(200106) 44: 6<1261:: A I D-A R-$ T217>3.0.C0;2-L, indexed in Pubmed: 11407684.
28. Kirsten $\mathrm{H}$, Petit-Teixeira $\mathrm{E}$, Scholz $\mathrm{M}$, et al. Association of MICA with rheumatoid arthritis independent of known HLA-DRB1 risk alleles in a family-based and a case control study. Arthritis Res Ther. 2009; 11(3): R60, doi: 10.1186/ar2683, indexed in Pubmed: 19409079.

29. López-Arbesu R, Ballina-García FJ, Alperi-López M, et al. MHC class I chain-related gene B (MICB) is associated with rheumatoid arthritis susceptibility. Rheumatology (Oxford). 2007; 46(3): 426-430, doi: 10.1093/rheumatology/kel331, indexed in Pubmed: 17003176.

30. Iwaszko M, Świerkot J, Kolossa K, et al. Polymorphisms within the human leucocyte antigen-E gene and their associations with susceptibility to rheumatoid arthritis as well as clinical outcome of anti-tumour necrosis factor therapy. Clin Exp Immunol. 2015; 182(3): 270-277, doi: 10.1111/cei.12696, indexed in Pubmed: 26307125.

31. Rizzo R, Farina I, Bortolotti D, et al. HLA-G may predict the disease course in patients with early rheumatoid arthritis. Hum Immunol. 2013; 74(4): 425-432, doi: 10.1016/j. humimm.2012.11.024, indexed in Pubmed: 23228398.

32. Lemire M. On the association between rheumatoid arthritis and classical HLA class I and class II alleles predicted from single-nucleotide polymorphism data. BMC Proc. 2009; 3 Suppl 7: S33, indexed in Pubmed: 20018024.

33. Vignal C, Bansal AT, Balding DJ, et al. Genetic association of the major histocompatibility complex with rheumatoid arthritis implicates two non-DRB1 loci. Arthritis Rheum. 2009; 60(1): 53-62, doi: 10.1002/art.24138, indexed in Pubmed: 19116923.

34. Toussirot E, Sauvageot C, Chabod J, et al. The association of HLA-DM genes with rheumatoid arthritis in Eastern France. Hum Immunol. 2000; 61(3): 303-308, indexed in Pubmed: 10689120.

35. Moxley G, Han J. HLA DMA and DMB show no association with rheumatoid arthritis in US Caucasians. Eur J Immunogenet. 2001; 28(5): 539-543, indexed in Pubmed: 11881821.

36. Eike MC, Skinningsrud B, Ronninger M, et al. CIITA gene variants are associated with rheumatoid arthritis in Scandinavian populations. Genes Immun. 2012; 13(5): 431436, doi: 10.1038/gene.2012.11, indexed in Pubmed: 22513452.

37. Bowness P. HLA-B27. Annu Rev Immunol. 2015; 33: 29-48, doi: 10.1146/annurev-immunol-032414-112110, indexed in Pubmed: 25861975.

38. Vitulano C, Tedeschi V, Paladini F, et al. The interplay between HLA-B27 and ERAP1/ERAP2 aminopeptidases: from anti-viral protection to spondyloarthritis. Clin Exp Immunol. 2017; 190(3): 281-290, doi: 10.1111/cei.13020, indexed in Pubmed: 28759104.

39. Urban RG, Chicz RM, Lane WS, et al. A subset of HLA-B27 molecules contains peptides much longer than nonamers. Proc Natl Acad Sci U S A. 1994; 91(4): 1534-1538, indexed in Pubmed: 8108441.

40. Uchanska-Ziegler B, Ziegler A, Schmieder P. Structural and dynamic features of HLA-B27 subtypes. Curr Opin Rheumatol. 2013; 25(4): 411-8.

41. Abualrous ET, Fritzsche $\mathrm{S}$, Hein Z, et al. F pocket flexibility influences the tapasin dependence of two differentially disease-associated MHC Class I proteins. Eur J Immunol. 2015; 45(4): 1248-1257, doi: 10.1002/eji.201445307, indexed in Pubmed: 25615938

42. Cortes A, Hadler J, Pointon JP, et al. International Genetics of Ankylosing Spondylitis Consortium (IGAS), Australo-Anglo-American Spondyloarthritis Consortium (TASC), 
Groupe Française d'Etude Génétique des Spondylarthrites (GFEGS), Nord-Trøndelag Health Study (HUNT), Spondyloarthritis Research Consortium of Canada (SPARCC), WelIcome Trust Case Control Consortium 2 (WTCCC2). Identification of multiple risk variants for ankylosing spondylitis through high-density genotyping of immune-related loci. Nat Genet. 2013; 45(7): 730-738, doi: 10.1038/ng.2667, indexed in Pubmed: 23749187.

43. Reeves E, Colebatch-Bourn A, Elliott $T$, et al. Functionally distinctERAP1allotype combinations distinguish individuals with Ankylosing Spondylitis. Proceedings of the National Academy of Sciences. 2014; 111(49): 17594-17599, doi: 10.1073/pnas.1408882111.

44. Sanz-Bravo A, Alvarez-Navarro C, Martín-Esteban A, et al. Ranking the Contribution of Ankylosing Spondylitis-associated Endoplasmic Reticulum Aminopeptidase 1 (ERAP1) Polymorphisms to Shaping the HLA-B*27 Peptidome. Mol Cell Proteomics. 2018; 17(7): 1308-1323, doi: $10.1074 / m c p . R A 117.000565$, indexed in Pubmed: 29632046.

45. Evans DM, Spencer CCA, Pointon JJ, et al. Spondyloarthritis Research Consortium of Canada (SPARCC), Australo-Anglo-American Spondyloarthritis Consortium (TASC), Wellcome Trust Case Control Consortium 2 (WTCCC2). Interaction between ERAP1 and HLA-B27 in ankylosing spondylitis implicates peptide handling in the mechanism for HLA-B27 in disease susceptibility. Nat Genet. 2011; 43(8): 761-767, doi: 10.1038/ng.873, indexed in Pubmed: 21743469.

46. Cortes A, Pulit SL, Leo PJ, et al. Major histocompatibility complex associations of ankylosing spondylitis are complex and involve further epistasis with ERAP1. Nat Commun. 2015; 6: 7146, doi: 10.1038/ncomms8146, indexed in Pubmed: 25994336.

47. Vargas-Alarcón G, Gamboa R, Zuñiga J, et al. Association study of LMP gene polymorphisms in Mexican patients with spondyloarthritis. Hum Immunol. 2004; 65(12): 14371442, doi: $10.1016 /$ j.humimm.2004.09.007, indexed in Pubmed: 15603870

48. Haroon N, Maksymowych W, Rahman P, et al. Radiographic severity in ankylos-ing spondylitis is associated with polymorphism in large multifunctionalpeptidase 2 (LMP2) in the SPARCC cohort. Arthritis Rheum. 2011; 64: 1119-26.

49. Qian $Y$, Wang G, Xue F, et al. Genetic association between TAP1 and TAP2 polymorphisms and ankylosing spondylitis: a systematic review and meta-analysis. Inflamm Res. 2017; 66(8): 653-661, doi: 10.1007/s00011-0171047-1, indexed in Pubmed: 28405734.

50. Illing PT, Vivian JP, Dudek NL, et al. Immune self-reactivity triggered by drug-modified HLA-peptide repertoire. Nature. 2012; 486(7404): 554-558, doi: 10.1038/nature11147, indexed in Pubmed: 22722860.

51. Colbert RA, Tran TM, Layh-Schmitt G. HLA-B27 misfolding and ankylosing spondylitis. Mol Immunol. 2014; 57(1): 44-51, doi: 10.1016/j.molimm.2013.07.013, indexed in Pubmed: 23993278.

52. Antoniou AN, Guiliano DB, Lenart I, et al. The oxidative folding and misfolding of human leukocyte antigen-b27. Antioxid Redox Signal. 2011; 15(3): 669-684, doi: 10.1089/ars.2010.3692, indexed in Pubmed: 21671754.

53. McHugh K, Bowness P. The link between HLA-B27 and SpA--new ideas on an old problem. Rheumatology (Oxford). 2012; 51(9): 1529-1539, doi: 10.1093/rheumatology/kes061, indexed in Pubmed: 22513152.
54. Wong-Baeza I, Ridley A, Shaw J, et al. KIR3DL2 binds to HLA-B27 dimers and free $\mathrm{H}$ chains more strongly than other HLA class I and promotes the expansion of T cells in ankylosing spondylitis. J Immunol. 2013; 190 (7): 3216-3224, doi: 10.4049/jimmunol.1202926, indexed in Pubmed: 23440420.

55. Robinson PC, Brown MA. Genetics of ankylosing spondylitis. Mol Immunol. 2014; $57(1)$ : 2-11, doi: 10.1016/j.molimm.2013.06.013, indexed in Pubmed: 23916070.

56. Díaz-Peña R, López-Vázquez A, López-Larrea C. Old and new HLA associations with ankylosing spondylitis. Tissue Antigens. 2012; 80(3): 205-213.

57. Wei JCC, Tsai WC, Lin HS, et al. HLA-B60 and B61 are strongly associated with ankylosing spondylitis in HLA-B27-negative Taiwan Chinese patients. Rheumatology (Oxford). 2004; 43(7): 839-842, doi: 10.1093/rheumatology/keh193, indexed in Pubmed: 15113995.

58. Yamaguchi A, Tsuchiya N, Mitsui $\mathrm{H}$, et al. Association of HLA-B39 with HLA-B27-negative ankylosing spondylitis and pauciarticular juvenile rheumatoid arthritis in Japanese patients. Evidence for a role of the peptide-anchoring B pocket. Arthritis Rheum. 1995; 38(11): 1672-1677, indexed in Pubmed: 7488289.

59. Bown MA, Jin R, Wordsworth BP, et al. et al.. HLA Class I and II associations of anky-losing spondylitis. Arthritis Rheum. 2009; 60(Suppl 10): 11716-11721.

60. Breban M, Costantino F, André C, et al. Revisiting MHC genes in spondyloarthritis. Curr Rheumatol Rep. 2015; 17(6): 516, doi: 10.1007/s11926-015-0516-1, indexed in Pubmed: 25903667.

61. Paladini $F$, Belfiore $F$, Cocco E, et al. HLA-E gene polymorphism associates with ankylosing spondylitis in Sardinia. Arthritis Res Ther. 2009; 11(6): R171, doi: 10.1186/ar2860, indexed in Pubmed: 19912639.

62. Santos MR, Couto AR, Foroni I, et al. Non-classical human leucocyte antigens in ankylosing spondylitis: possible association with HLA-E and HLA-F. RMD Open. 2018; 4(1): e000677, doi: 10.1136/rmdopen-2018-000677, indexed in Pubmed: 30018800.

63. Zhou X, Wang J, Zou H, et al. MICA, a gene contributing strong susceptibility to ankylosing spondylitis. Ann Rheum Dis. 2014; 73(8): 1552-1557, doi: 10.1136/annrheumdis-2013-203352, indexed in Pubmed: 23727634.

64. Lenz TL, Deutsch AJ, Han B, et al. Widespread non-additive and interaction effects within HLA loci modulate the risk of autoimmune diseases. Nat Genet. 2015; 47(9): 1085-1090, doi: 10.1038/ng.3379, indexed in Pubmed: 26258845.

65. Wei WH, Loh CY, Worthington J, et al. Immunochip Analyses of Epistasis in Rheumatoid Arthritis Confirm Multiple Interactions within MHC and Suggest Novel Non-MHC Epistatic Signals. J Rheumatol. 2016; 43(5): 839-845, doi: 10.3899/jrheum.150836, indexed in Pubmed: 26879349.

66. Wei WH, Bowes J, Plant D, et al. Major histocompatibility complex harbors widespread genotypic variability of non-additive risk of rheumatoid arthritis including epistasis. Sci Rep. 2016; 6: 25014, doi: 10.1038/srep25014, indexed in Pubmed: 27109064.

67. Spurlock CF, Tossberg JT, Olsen NJ, et al. Cutting Edge: Chronic NF- B Activation in CD4+ T Cells in Rheumatoid Arthritis Is Genetically Determined by HLA Risk Alleles. J Immunol. 2015; 195(3): 791-795, doi: 10.4049/jimmunol.1500267, indexed in Pubmed: 26091715. 
68. Khan MA. An Update on the Genetic Polymorphism of HLA-B*27 With 213 Alleles Encompassing 160 Subtypes (and Still Counting). Curr Rheumatol Rep. 2017; 19(2): 9, doi: 10.1007/s11926-017-0640-1, indexed in Pubmed: 28247302.

69. Saad MN, Mabrouk MS, Eldeib AM, et al. Identification of rheumatoid arthritis biomarkers based on single nucleotide polymorphisms and haplotype blocks: A systematic review and meta-analysis. J Adv Res. 2016; 7(1): 1-16, doi: 10.1016/j.jare.2015.01.008, indexed in Pubmed: 26843965.

70. Kim K, Bang SY, Lee HS, et al. Biologics in Rheumatoid Arthritis Genetics and Genomics Study Syndicate, Wellcome Trust Case Control Consortium. High-density genetic mapping identifies new susceptibility loci for rheumatoid arthritis. Nat Genet. 2012; 44(12): 1336-1340, doi: 10.1038/ng.2462, indexed in Pubmed: 23143596.

71. Reveille JD, Sims AM, Danoy P, et al. Australo-Anglo-American Spondyloarthritis Consortium (TASC). Genome-wide association study of ankylosing spondylitis identifies non-MHC susceptibility loci. Nat Genet. 2010; 42(2): 123-127, doi: 10.1038/ng.513, indexed in Pubmed: 20062062.

72. Khan MA. Polymorphism of HLA-B27: 105 subtypes currently known. Curr Rheumatol Rep. 2013; 15(10): 362, doi: 10.1007/s11926-013-0362-y, indexed in Pubmed: 23990399.

73. Blanco-Gelaz MA, Suárez-Alvarez B, González S, et al. The amino acid at position 97 is involved in folding and surface expression of HLA-B27. Int Immunol. 2006; 18(1): 211-220, doi: 10.1093/intimm/dxh364, indexed in Pubmed: 16361312.

74. Isernhagen $A$, Malzahn $D$, Bickeböller $H$, et al. Impact of the MICA-129Met/Val Dimorphism on NKG2D-Mediated Biological Functions and Disease Risks. Front Immunol. 2016; 7: 588, doi: 10.3389/fimmu.2016.00588, indexed in Pubmed: 28018354.

75. Achour $\mathrm{Y}$, Ben Hamad M, Chaabane S, et al. Analysis of two susceptibility SNPs in HLA region and evidence of interaction between rs6457617 in HLA-DQB1 and HLA-DRB $1{ }^{*} 04$ locus on Tunisian rheumatoid arthritis. J Genet. 2017; 96(6): 911-918, indexed in Pubmed: 29321349.

76. Li Z, Brown MA. Progress of genome-wide association studies of ankylosing spondylitis. Clin Transl Immunology.
2017; 6(12): e163, doi: 10.1038/cti.2017.49, indexed in Pubmed: 29333268.

77. Ramsuran V, Kulkarni S, O'huigin C, et al. Epigenetic regulation of differential HLA-A allelic expression levels. Hum Mol Genet. 2015; 24(15): 4268-4275, doi: 10.1093/hmg/ddv158, indexed in Pubmed: 25935001.

78. Moreau P, Flajollet S, Carosella ED. Non-classical transcriptional regulation of HLA-G: an update. J Cell Mol Med. 2009; 13(9B): 2973-2989, doi: 10.1111/j.1582-4934.2009.00800.x, indexed in Pubmed: 19508383.

79. Wright $\mathrm{KL}$, Ting JPY. Epigenetic regulation of MHC-II and CIITA genes. Trends Immunol. 2006; 27(9): 405-412, doi: 10.1016/j.it.2006.07.007, indexed in Pubmed: 16870508.

80. Kato M, Yasuda S, Atsumi T. The role of genetics and epigenetics in rheumatic diseases: are they really a target to be aimed at? Rheumatol Int. 2018; 38(8): 1333-1338, doi: 10.1007/s00296-018-4026-0, indexed in Pubmed: 29623390.

81. Kolarz B, Majdan M. Epigenetyczne uwarunkowania reumatoidalnego zapalenia stawów: wpływ metylacji DNA i modyfikacji białek histonowych. Postępy Hig Med Dosw (online. 2017; 71: 1070-1079.

82. Ballestar E, Li T. New insights into the epigenetics of inflammatory rheumatic diseases. Nat Rev Rheumatol. 2017; 13(10): 593-605, doi: 10.1038/nrrheum.2017.147, indexed in Pubmed: 28905855

83. Liu Y, Aryee MJ, Padyukov L, et al. Epigenome-wide association data implicate DNA methylation as an intermediary of genetic risk in rheumatoid arthritis. Nat Biotechnol. 2013; 31(2): 142-147, doi: 10.1038/nbt.2487, indexed in Pubmed: 23334450.

84. van Steenbergen HW, Luijk R, Shoemaker R, et al. Differential methylation within the major histocompatibility complex region in rheumatoid arthritis: a replication study. Rheumatology (Oxford). 2014; 53(12): 2317-2318, doi: 10.1093/rheumatology/keu380, indexed in Pubmed: 25273994

85. Guo S, Zhu Qi, Jiang T, et al. Genome-wide DNA methylation patterns in CD4+ T cells from Chinese Han patients with rheumatoid arthritis. Mod Rheumatol. 2017; 27(3): 441-447, doi: 10.1080/14397595.2016.1218595, indexed in Pubmed: 27585642 